\title{
Architectural Violence, Architectural Power: The Fall of the Post-Political and the New Empowerment
}

\author{
MICHAEL MURPHY \\ MASS Design Group
}

\begin{abstract}
Violence has come to define and accelerate our architectural epochs. In the erection, abandonment, or destruction of architecture, buildings reveal shifts in economic and political power. Violence accompanies these shifts, fear reveals cracks in theory and discipline, and new architectural paradigms emerge. However, the types of violence that follow these shifts are not well defined. Is violence, as Tschumi offered, metaphor, or does it present a more fundamental crisis in our discipline? The power of architecture-its very agency in contributing to the social change it accompanies-is resized within the parameters of each political epoch.
\end{abstract}

\section{THE DEATH OF POSTMODERNISM}

The death knell of modernism rang in tune with the violence of collapsed buildings. In his 1974 manifesto The Language of Post-Modern Architecture, historian and landscape architect Charles Jencks time-stamped this moment at 3:32 p.m., July 15, 1972-the instant when Minoru Yamasaki's infamous PruittIgoe public housing project in St. Louis was demolished after it was decided that it was a terrifying and unlivable environment for the people it housed. ${ }^{1}$ As the city council claimed, "it was impossible to control any longer the violence it generated." ${ }^{2}$

Violence has come to define and accelerate our architectural epochs. In the erection, abandonment, or destruction of architecture, buildings reveal shifts in economic and political power. The cracks in our buildings can be read as cracks in regimes. When violence occurs, fear sets in, those cracks expand, and a new architectural paradigm emerges. Architectural styles and theory follow, and the power of architecture-its very agency in contributing to the social change it accompanies-is resized within the parameters of each political epoch.

When Jencks and his contemporaries named the end of modernism, it was during a reflective moment where the promises that modernism offered of social change and uplift remained unfulfilled. The 1970s were challenging times-an economic downturn, an energy crisis, global unrest after 1968, and a hangover from public projects viewed as violent disasters. ${ }^{3}$ Architects and planners came under attack for this violence and their relationships to power. ${ }^{4}$ And many architects distanced themselves from the architecture that espoused an ambition for social change, what architect Denise Scott Brown labeled the "unthinking, authoritarian and socially coercive stance taken by Modern architects in the 1950s and 1960s." ${ }^{15}$

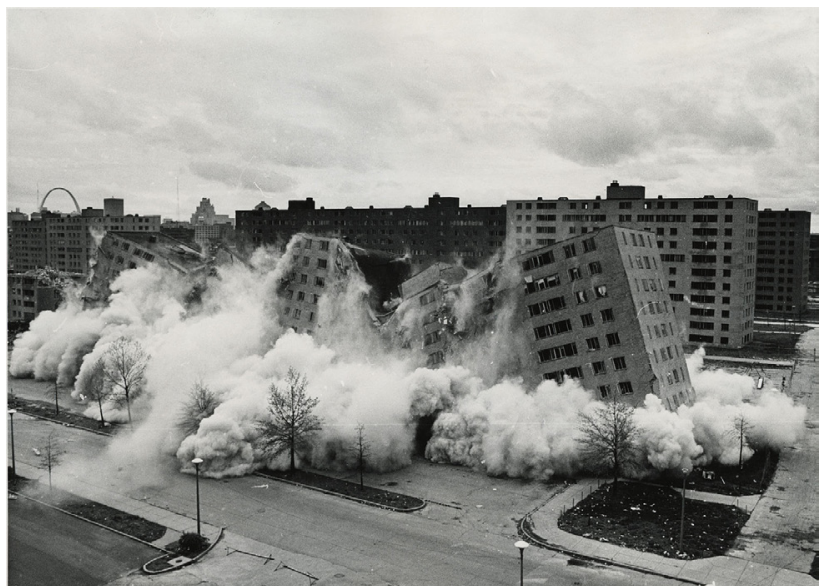

Figure 1: Pruitt-Igoe, July 15, 1972. (U.S. Department of Housing and Urban Development)

Scott Brown's partner, Robert Venturi, suggested that architects needed to "narrow" their purview in response to a growing ineffectualness. Power, Venturi argued, should be left to the powerful. ${ }^{6}$ Instead architects ought to focus on the language of buildings, the symbolism and meaning, the complexity and contradiction that their forms project. In an interview with the architectural historian Enrique Walker, the architect Bernard Tschumi concurred: "Architecture was considered to be tied to power-the power of the state, the power of money, the power of multinational corporations, the power of capitalist society-and therefore, there was absolutely no way it could transform the power structure of society."

If architecture could change power relations-if it was indeed embedded in and reifying of such social structures-could it, and the architects that designed them, be blamed for violent impacts that buildings can be complicit in? And if not, if architecture is instead powerless in the face of social and political change, then what agency can we mine for architecture? Moreover, who is accountable for what so many have labeled the violence of buildings, and how do we keep track of its many seemingly irreconcilable definitions?

The April 1993 issue of Assemblage (20: Violence, Space) included 40 concise reflections from practitioners, theorists, and artists on the relationship between space and violence; and Bechir Kenzari's recent edited publication, Architecture and Violence confronts the existence of violence within the profession. Both invite various authors to reflect on this 


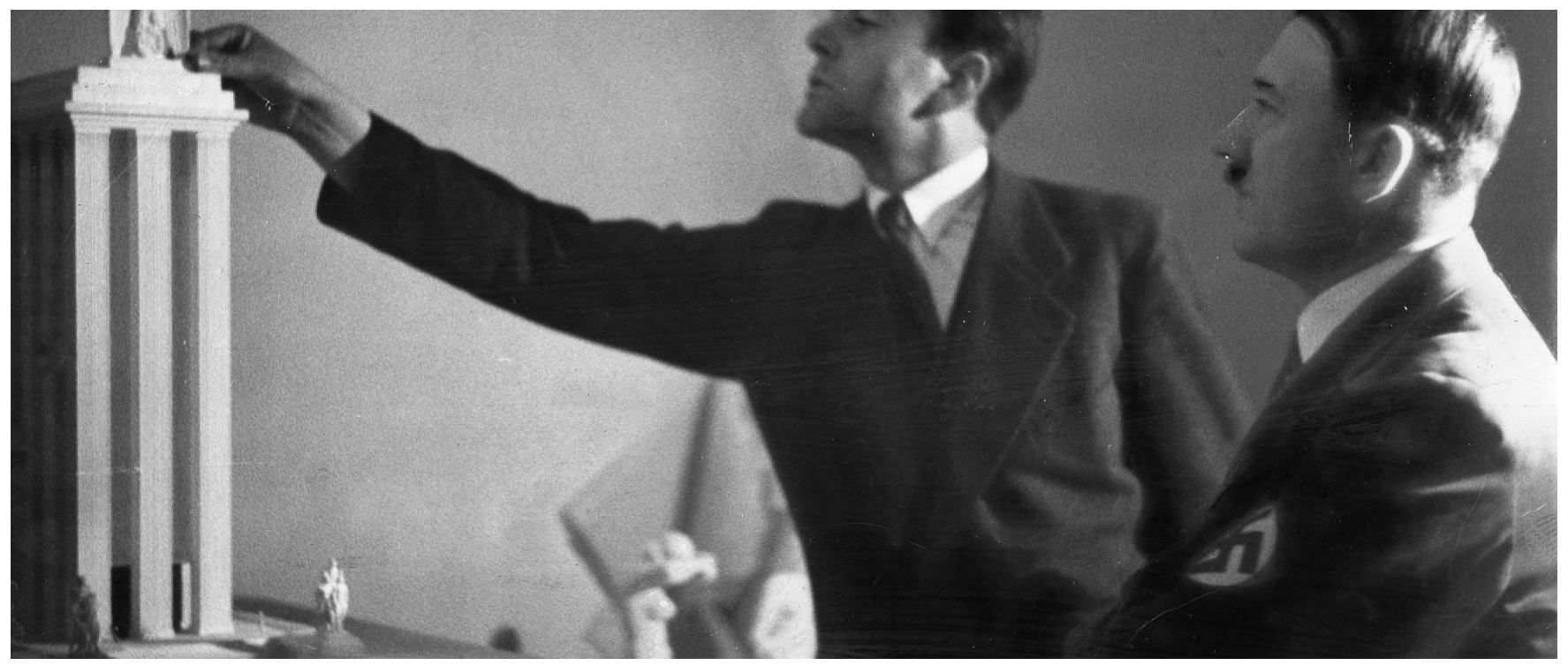

Figure 2: Albert Speer and Adolf Hitler examine a model of the German Pavilion for the World's Fair, 1937. (Photo: Süddeutsche Zeitung)

provocative marriage of violence and space. And with each reflection as many definitions emerge, all pointing towards a shared belief that buildings have the potential to inflict harm; but not a shared vocabulary of how or in which manner. Without such clarity, the public is deprived of the tools to address architectural violence when they encounter it, and practice is left debating whether architecture is still a weak political tool. New contemporary practices seemed primed to take this challenge on, but without a shared critical vocabulary, this zeitgeist threatens to dissipate when the pendulum swings again to a theoretical project aimed at appearing post-political.

This essay seeks to define the violence of architecture by separating out what it is not. Such a theoretical inquiry we hope will temper the fire of hyperbole in order to take seriously the violence of intent. We want also to call out the violence of complicity and negligence inherent in our profession as it relates to power in order to weed it out.

Bernard Tschumi's 1981 essay, "Violence of Architecture" indirectly indexes a working framework for various different types of violence that architecture had historically been blamed for. While taking his essay out of its early 1980 s context, we have found this piece illustrative of a way to organize five "orders," or typologies of violence, each with varying degrees of visibility and intent.

\section{FIRST ORDER}

The first order is the most obvious form of violence-physical and psychological injury. Tschumi starts by identifying what he calls the "brutality" of buildings by describing a building's capacity for inflicting physical or psychological violence on a subject by collapse or destruction. While perhaps extreme, a building's collapse recalls the social contract architecture has with the public: at the very least, a building should remain standing and keep bodies safe.

Recent scientific research shows that this contract has been breached. Buildings can cause illness, release carcinogenic fumes, and incubate and cause disease transfer, not to mention collapse on their inhabitants. But maybe most persuasive is how physical spaces can directly injure inhabitants themselves. Recent journalistic work on prisons and the mental effects of extended isolation implicate the prison spaces themselves with the long-term degradation of psyches. A New York Times piece from 2015 titled "inside America's Toughest Federal Prison" revealed in illustrative detail how years of isolation in a prison can lead to constant self-harm, severe psychological degradation resulting from mentally instability, and progressive behavioral change from a healthy profile to a deranged psychotic state. ${ }^{8}$

As the Times article suggests, a correlation can be drawn between the space of the prison and the constant isolation within this space and the gradual 'breaking' of the inmates. The literature and codes associated with prison architecture supports the intent to design spaces of austere materials and to control behavior by separation, to resist access to natural light, and to establish an environment whose effects on inmates that could only be described as punitive and violent.

Tschumi's essay does not delve into this order of direct architectural violence. Instead, he seeks to establish a definition of architectural violence that is more metaphysical (what we call the Fifth Order) and so he acknowledges this order, but diverts his focus away from the inquiry of physical or mental injury. "By 'violence,"' he states, "I do not mean the brutality that destroys physical or emotional integrity but a metaphor for the intensity of a relationship between individuals and their surrounding spaces."9 


\section{SECOND ORDER}

The second order of architectural violence is associated with the function of a building, and how certain building functions are intended to overtly harm and control individuals. What Tschumi refers to as "programmatic violence" implicates buildings like the slaughterhouse, the prison, the asylum, and the concentration camp: structures that have an explicit programmatic function for killing, for torture, or for social and cultural isolation. While the prison emerges again in this order, the torture chamber is more functionally intended to 'torture', the slaughterhouse to slaughter, the concentration camp to concentrate.

But there are also other kinds of programmed violence that are not intentional. Pruitt-Igoe, while designed with "good" intentions of solving urban poverty, had failed to anticipate the impacts of its high population density and of its spatial design on behavior. The modernist "streets in the sky" concept manifested in long hallways, dark stairwells, and infamous "skip-stop" elevators, which rendered it difficult to control space or distinguish between neighbor and visitor. Combined with a lack of maintenance and management that bordered on intentional negligence, the modernist rigidity of Pruitt-Igoe only inflamed an environment of fear that was counterproductive to the modernist ideology of behaviorism and offered an argument for moving beyond functionalism, which had so clearly fallen short. ${ }^{10}$

The staggering deterioration of Pruitt-Igoe prompted Yamasaki to state, "I never thought people were that destructive," essentially placing the blame on its users. ${ }^{11}$ When it was finally decided that it was no longer inhabitable-only 14 years after it was constructed-Pruitt-Igoe was mercifully dynamited. "It's a job I wish I hadn't done," Yamasaki added, acknowledging some complicity in its violent devolution. ${ }^{12}$

\section{THIRD ORDER}

The third order, what Tschumi refers to indirectly as "style," suggests that the language and form of architecture should not be considered more or less violent than any other "style" of architecture. The International Style modernism of PruittIgoe obfuscated its intent to be segregated by race-Igoe for whites, Pruitt for blacks. Until a federal injunction ended this practice, the horizontal lines of the towers in the field rendered neutral the racial bias of a state required to relocate thousands of poor people into "modern" accommodations.

But what about more overtly violent state styles, like the neoclassical architecture of the Third Reich or fascist Italy? Should this architecture be considered on a scale, as being more "violent" than other buildings? Hitler and Mussolini understood architecture as propaganda, utilizing style, symbolism, and form to legitimatize power by inspiring awe, inducing fear, and executing each regime's totalitarian mission. The threat of violence was ever-present. As Kenzari notes: "It is no secret... that fascism used architects to glorify itself at all levels...Architects whether they admit it or not, can become powerful leaven for violence." ${ }^{13}$

Yet for theorists auguring for autonomy, the style of a building had to be rendered neutral. "No more or less violent," as Tschumi states, "than classical architecture, or than fascist, socialist, or vernacular variations." 14 But is this claim even possible? Can the very built symbols of genocidal or autocratic states-its architecture, its aesthetic-be extracted from the political context that built them? This question of whether we can neutralize architectural style from its political influence consumed them. And the discussion of the Nazi regime and its architecture in particular, appeared repeatedly as a foil to explain a new theory that recently Alejandro Zaera-Polo have termed the era of Post-political architecture-a strand of post-modernism that as Michael Graves famously noted in 1981, "thank god politics has left architecture, so we can get on with real architecture."

The spring 1978 issue of the architecture journal Oppositions offers some insight into how this theoretical project developed. The entire journal was dedicated to fascist architecture and the provocative stance that it was deserving of formal study. In this issue, architectural theorist Kenneth Frampton presented a survey of fascist architecture, "The Synoptic View of the Architecture of the Third Reich," while architectural historians Francesco Dal Co and Sergio Polano interviewed Albert Speer himself, Hitler's architect and convicted war criminal. ${ }^{15}$

Dal Co and Polano did not hide the depoliticizing intent of such exhumation: "The history of the architecture of totalitarian regimes", they began, "cannot be allowed to enter into that historiographical mythology ... of the reductive and consoling hypothesis [that] the architecture of Albert Speer [is] synonymous with Nazi Architecture."16 Such revelation and 're-reading' should not suggest that these architects, many from the political left, were defending or intending to validate the Nazi regime or the Holocaust, but the compound effect of such 'neutral inquiry' in Oppositions is a humanization of Speer the person, and the laborious effort to talk about his architecture outside of its political and genocidal context. It behooves the question of whether such inquiry is even possible, and was Albert Speer, used as s foil to advance a theoretical project to make architecture post-political.

Team Ten's Giancarlo De Carlo's contemporaneous warnings about such theoretical gymnastics were largely proven prescient and accurate. Writing at the same time as Oppositions, in his 1978's inaugural issue of his architectural magazine Space and Society, he warns of the winds of postmodernism's retreat to the formal, and attempt at the post-political. The two are intertwined he notes: 


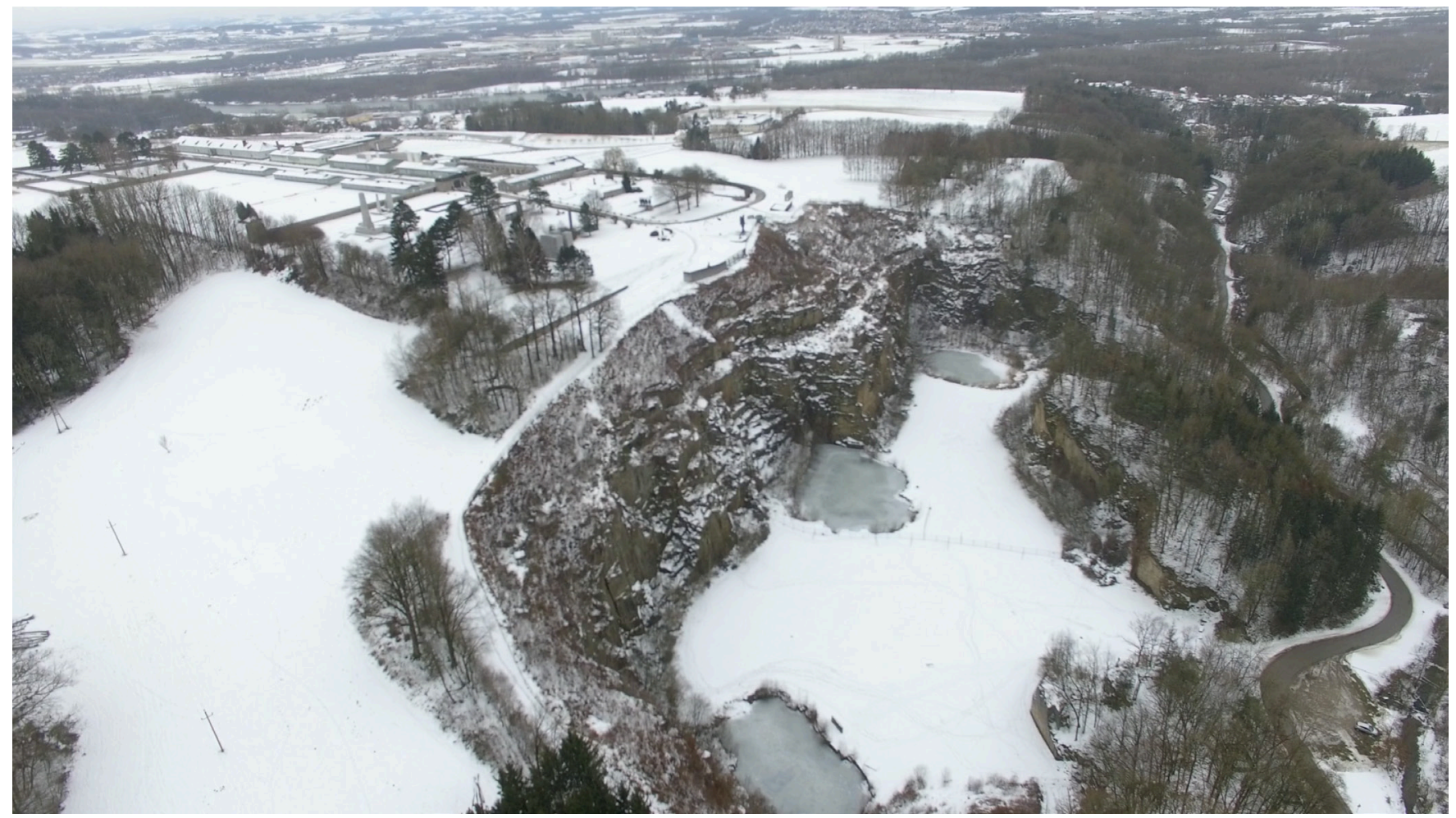

Figure 3: Mauthausen Concentration Camp in winter 2017, with quarry in foreground. (Photo by author)

"Contemporary architecture tends to produce objects while its real role should be that of generating processes. This distortion has very serious consequences for it confines architecture to a very narrow strip of a whole spectrum, so segregating it, leaving it open to the risks of dependency and megalomania, and leading it to social and political indifference."17

Recent revelations about Speer in a new biography written by historian Martin Kitchen also substantiate De Carlo's warnings. Kitchen tells that Speer had clear knowledge of the genocidal ambitions of Hitler's plans. More damning, Kitchen depicts Speer as fervently complicit. Speer not only used eminent domain to grab Jewish property in Berlin but also abused slave labor in the concentration camps to source the granite he desired to rebuild Berlin. He went so far as to place new concentration camps at profitable stone quarries. ${ }^{18}$ And in the most complicitous incident, he approved the expansion of Auschwitz and other camps whose primary purpose was to resolve "the Jewish question."19

\section{FOURTH ORDER}

"Speer had an insatiable thirst for granite," journalist Michael Lewis tells us. ${ }^{20}$ But such thirst was predicated on the capability to source and mine an enormous quantity of stone, and so the use of slave labor and the placing of concentration camps adjacent to stone quarries-Mauthausen, Gross-Rosen, Buchenwald, Flossenbürg, and Liban-were decisions made by Speer. The Führer's architect famously made only one visit to a concentration camp, at Mauthausen, known for its "stairs of death' and remarked how wasteful it was to construct the prisoners' quarters out of granite when the material and the labor could otherwise be utilized to build Hitler's Berlin and supply the war effort. Promptly, Speer ordered "an immediate switch to primitive construction methods," resulting in windowless wooden barracks that housed up to 400 people each, many of whom froze to death. ${ }^{21}$

Certainly in this new history Speer himself was aware of the programmatic violence (second order) of his intended designs. But the complicity within his material specification and site location reveal a long trail of injury resulting from the architect's choices. Speer's decisions are examples that show even the minutia of material sourcing and associate labor selection can cause environmental and social degradation. Whether we acknowledge it or not, these choices can be acts of violence.

This fourth type of violence was not mentioned by Tschumi's essay; but recent controversy over labor abuse and worksite deaths has emerged as a primary way to read our built world. What philosopher Slavoj Žižek calls "systemic violence" refers to the decisions of power that reinforce the sometimes invisible systems of subjugation. ${ }^{22}$

Seen through this lens, architecture can be an instrument of systemic violence far too often. The choices for a materials and location, size and program create environmental footprints and human handprints. Aggregated over the entire lifespan of a building, the acts of ethical material selection 


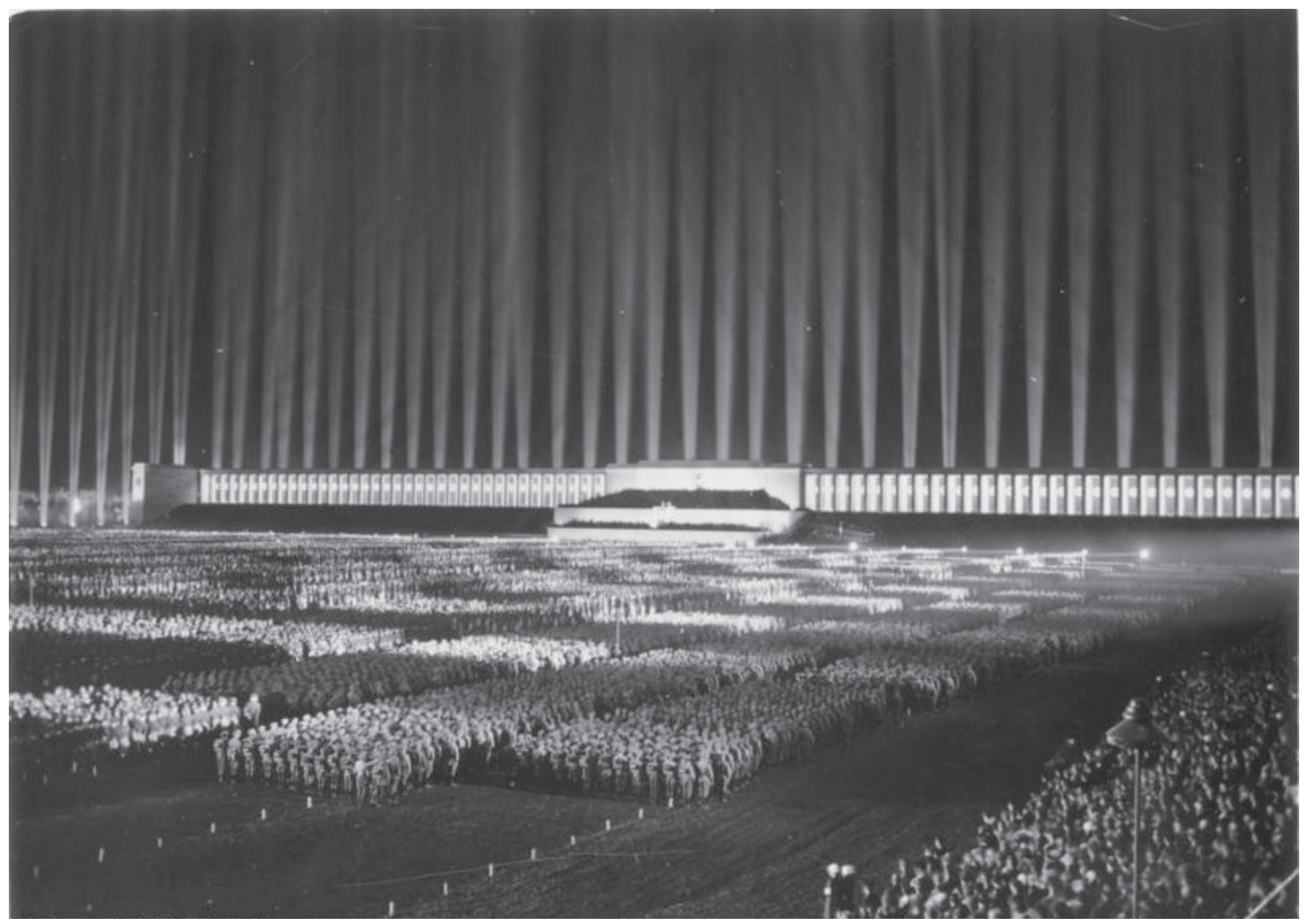

Figure 4: The Cathedral of Light at Nürnberg, Albert Speer, 1936. (Deutsches Bundesarchiv)

and equitable labor composition can work to acknowledge and reduce the systemic violence embedded within the bricks and mortar of architecture. Architects often claim they are 'powerless' in the face of these deeply entrenched and sometimes national systems of abuse and injustice, but we must ask, are we truly powerless, or without the tools to resist?

In the case of Speer, the previous four types of architectural violence all appear and converge. His buildings killed; they were designed to torture, separate, and test the human limits of suffering. His structures were designed in a style to represent and legitimize the political ambitions of the state and the timelessness of its ideas, and they were built in a manner of systemic injury and violence against humans. But refusing to tease out these relationships creates a scatter shot understanding of where our choices are ones of negligence or empowerment, of injury or justice, and of pollution or restoration by our profession.

But for the editors of Oppositions, distancing architects from complicity in building was too tantalizing a defense for architecture more broadly. ${ }^{23}$ As architect Leon Krier in his monograph on Albert Speer extolled, if "a war criminal [can] be a great artist" than maybe architects can focus on what they know they can control-the "form," not the "content" of the built world. ${ }^{24}$ Such efforts to depoliticize architecture from the regimes of their practice, what Žižek calls the violence of criticism, eventually just becomes the same thing-an act of violence itself. ${ }^{25}$

\section{FIFTH ORDER}

Instead, architects sought answers inward, searching for architectural agency in the subconscious and the experiential. Here Tschumi's essay stretches the definition of architectural violence to the metaphor in order to illustrate the disconnect between the function of a space and its actual use. A factory loft being used as a home or the act of pole vaulting in St. Peter's Church are violations of the intended function of a building and are therefore violent disruptions to our psychospatial expectations. ${ }^{26}$ Tschumi wrote: "[When you] abandon your imaginary spatial markings ... you lose your identity as a subject."27 And in some cases, this ritual regression is desirable: "It must be stressed that the receiving subject-you or I-may wish to be subjected to such spatial aggression...The love of violence, after all, is an ancient pleasure."28 
In Tschumi's defense, architecture surely does more than we can measure. It influences our subconscious, it challenges the prescribed use and function of its 'intent', and it evolves over time to become something impossible to fully control and fix outcomes onto. Tschumi's contribution reminds us that this disorientation, can also orient a deeper ontological view of our selves, and our psyches in space. He calls these 'traumatic shifts' acts of violence, but after this close reading, we must ask is this provocation hyperbolic or oversimplified in using the term violence, where instead disorientation, dislocation, or disjuncture might be more appropriate?

Regardless, Tschumi's essay and framework are helpful to question Tschumi's other claim that architecture was a "weak political tool for transforming our existing society," ${ }^{29}$ for is not the acknowledgement of its potential to incite fear-the psychological threat of violence-and conversely its potential to design against violent outcomes and even produce pleasure, itself an opportunity to restore its political agency?

\section{THE POST-POST-POLITICAL}

The efforts to remove politics from the architecture of a genocidal state reads today like a perverse effort of theoretical subterfuge. But such efforts to attempt to read architecture apolitically continue today-causing confusion in theory and practice for generations of architects who wrestle with what their role is in resisting political regimes, advocating for the poor, and specifying material and labor ethically. Certainly the choices of architects shape the forms, functions, and fictions that become our reality but what architects control of the process is still in play.

Alejandro Zaera-Polo in his essay, "Well into the $21^{\text {st }}$ Century, the Architecture of Post-Capitalism" suggests that young practitioners emerging after the crash of 2018 and its concomitant challenges to neoliberalism and globalization are driving the post-political era towards its end. Zaera-Polo diagrams one hundred young practices to seek those that address a "post-capitalist future, and which ones are merely reacting against the late-capitalist ones." Zaera Polo's exercise reveals shared methods and new processes for architecture to engage in power relationships outside of the commodification that formal inquiry alone engenders.

Whether post-capitalist practice remains utopian, ZaeraPolo's map suggests many practices share an effort to restructure the power relationships inherent in the built world: one methodology in addressing violence. As he states:

"Practices have become engaged with direct-action practices formerly associated with political agitation, while occupying a space between social activism, art installation, and architecture.... These practices are both collectively and individually retrieving the cathartic value of the act of building to mobilize social consciousness and re-engage the architectural object with community, albeit through the much-reduced budgets of late, which have become a source of pride rather than derision." ${ }^{\prime 30}$

Forty years after the claimed death of modernism, we are in a new epoch that resurfaces some of the optimism of the modern era and attempts to face the violence the built world facilitates:

"There are now quite a few practices where the rejection of the customary processes of architectural procurement is driving a return to development, self-building, or community-building as an act of resistance against the rote commodification of architecture. Drawing resources sometimes from arts grants, academic research, community funding, and, on occasion, entrepreneurial devices..." ${ }^{31}$

Recent Pritzker Prize winners Alejandro Aravena and Shigeru Ban suggest a shift in the canon that proposes awards and recognition. Both practices represent the expanded reach of work and have developed practice models to accommodate emergency relief and social housing. While not overtly political practices, they embrace a position that acknowledges their political position, as designers, to engage their communities and to engender social change.

The history of practices that resist the anti-political have a long lineage: both Aravena and Ban can trace their inquiries to Wiliam Morris, Lina Bo Bardi, Giancarlo De Carlo, Team Ten, and ATBAT Afrique, among others. To De Carlo, who had survived fascist Italy, the Pruitt Igoe failed not because of its noble attempts to solve poverty but because modernists spoke the language of industry-efficiency and scale and replication and prototypes-instead of the language of dignity and humanity. The question is not how many units we need to build, but instead how do we build each person their own palace?

In foregrounding processes over products, the work of early post-war architectural efforts like De Carlo, and ATBAT Afrique not only endures today, but projects like the Carrieres Centrales in Casablanca or the housing in Terni provide a symbolic lesson in how architecture can improve people's lives and become integrated with their daily lives, rather than offering opposing or violently altering ways of life. Over time, inhabitants have organically altered Carrieres Centrales; today it is no longer the recognizable structure it once was, but in its evolution it also provides a valuable lesson that Aravena has seemingly taken and made his own with the Half-a-house project. By embracing architecture as process, a number of emerging and established practices, are today eschewing both the grand project of modernism and the socially-adverse project of autonomy to design processes and products that take the well-being of their inhabitants in account. In this way, they are even empowering, because they shift power relationships to those who will inhabit 
them. This era might be called the New Empowerment, for it acknowledges the power of architecture, but seeks to share that power with the constituents and communities it serves.

\section{Such architecture reduces violence.}

When architect Patrik Schumacher responded to critiques of Zaha Hadid Architects and the Pritzker medals being given to Aravena with a rant against the "political correctness" of architecture, he exhumed the post-political whitewash . "STOP political correctness in architecture," he wrote, "architects are in charge of the form of the built environment, not its content." Any public pressure on architects to "demonstrate a manifest tangible benefit for the poor" he continued, was "paralyzing" to architects creatively and 'arrests' their ability to explore and experiment "as if the delivery of social justice is the architect's competency." ${ }^{132}$ Schumacher pulls a page from the post-political playbook: lambast functionalism, proclaim architecture autonomous, and hope the violence and demagoguery of patrons might be rendered unrelated to formal agenda.

But, as the long list of new practitioners show, architects can design against injury and fear, and increase agency and accountability without pandering to a neoliberal binary of form versus purpose. Instead, the belief that architecture is never neutral has gained wide embrace, and any effort to depoliticize architecture is an act of violence itself. We can also read such efforts as Schumacher's for what they are, the last voice of a dying argument, and the end of an epoch. The post-political project is dead, long live the New Empowerment.

\section{ENDNOTES}

1 Charles Jencks, The Language of Postmodern Architecture (New York: Rizzoli, 1975), 9.

2 From an editorial by architect Giancarlo de Carlo under the pseudonym Heres Jedece, "Are the ways of architecture really infinite?" Space and Society 2 (April 1978): 85

3 "The hoped for condition did not ensure," architecture theorist Colin Rowe wrote in 1972, "the intensity of [architecture's] social mission became distanced." Colin Rowe, Introduction to Five Architects (New York: Rizzoli, 1972), reprinted in K. Michael Hays, Architectural Theory Since 1968 (Cambridge, MA: MIT Press, 1998), 75

4 Jane Jacobs's seminal 1961 book, The Death and Life of Great American Cities, was among the most popular and stinging critiques of large-scale, midcentury urban renewal projects for their privileging of the automobile and lack of human scale, an outcome that came to be associated with modern architecture, especially in the United States.

5 Denise Scott Brown, "On Architectural Formalism and Social Concern: A Discourse for Social Planners and Radical Chic Architects," Oppositions 5 (Summer 1976): 103. Italics added.

$6 \quad$ "The architect's ever diminishing power and his growing ineffectualness in shaping the whole environment can perhaps be reversed, ironically, by narrowing his concerns and concentrating on his own job. Perhaps then relationships and power will take care of themselves." Robert Venturi, Complexity and Contradiction in Architecture (New York: Museum of Modern Art, 1977), 14.

7 Bernard Tschumi and Enrique Walker, Tschumi on Architecture: Conversations with Enrique Walker (New York: Monacelli Press, 2006), 15-17.

8 Mark Binelli, "Inside America's Toughest Federal Prison," The New York Times, <https://www.nytimes.com/2015/03/29/magazine/inside-americastoughest-federal-prison.html $>$ accessed Mar 26, 2015.
9 Tschumi, "Violence of Architecture," in Architecture and Disjunction (Cambridge, MA: MIT Press, 1996), 122.

10 Rainwater frames the importance of Pruit-Igoe: "No other public housing project in the country approaches it in terms of vacancies, tenant concerns and anxieties, physical deterioration. Rather, Pruitt-Igoe is interesting precisely because it condenses into one 57 -acre tract all of the problems and difficulties that arise from race and poverty, and all of the impotence, indifference, and hostility with which our society has so far dealt with these problems. Processes that are sometimes beneath the surface in less virulent slums are readily apparent in Pruitt-Igoe. And because Pruitt-Igoe exists as one kind of Federal Government response to the problems of poverty, the failure of that response is worth contemplating." Lee Rainwater, Behind Ghetto Walls: Black Families in a Federal Slum (New Brunswick, NJ: Aldine, 2006), 3.

11 Yamasaki quoted in Colin Marshall, "Pruitt-Igoe: The Troubled High-Rise that Came to Define Urban America," The Guardian, April 22, 2015, <http://www. theguardian.com/cities/2015/apr/22/pruitt-igoe-high-rise-urban-americahistory-cities>, accessed Mar 26, 2015

12 Ibid.

13 Bechir Kenzari, ed., "Introduction," in Architecture and Violence (Barcelona: Actar, 2011), 15

14 Tschumi, "Violence of Architecture," 122.

15 The interview with Speer in Oppositions also gives room for his defense: an ignorance of intent, a lack of knowledge of the grand plan, which, as Susan Sontag notes in her 1975 essay in The New York Review of Books on Leni Riefenstahl's "Fascinating Fascism," creates a defensive distance between Speer's effort to make great artwork and the broader genocidal agenda of the Nazi regime. As Sontag notes, Riefenstahl leveraged the renewed interest in her films during the 1970s to distance her intimate relationship with Hitler and promote her films as cinéma vérite instead of propaganda.

16 Francesco Dal Co and Sergio Polano, "Interview with Albert Speer," Oppositions 12 (Spring 1978): 39.

17 Giancarlo De Carlo, “Opening Editorial," Space and Society 1 (1978), 5.

18 Martin Kitchen, Speer: Hitler's Architect (New Haven, CT: Yale University Press, 2015)

19 Michael J. Lewis, "The Architect of the Reich," New Criterion, March 2016 <https://www.newcriterion.com/articles.cfm/The-architect-of-theReich-8384>, accessed Apr 12, 2017

20 Ibid.

21 Kitchen, 158-159; also see Gitta Sereny, Albert Speer: His Battle with the Truth (New York: Vintage, 1995).

22 Slavoj Žižek, Violence (New York: Picador, 2008), 2.

23 Peter Eisenman-editor of Oppositions-would eventually exhume his masterwork on Giuseppe Terragni, the Italo-fascist architect, in Giuseppe Terragni: Transformations, Decompositions, Critiques (New York: Monacelli Press, 2003)

24 Leon Krier, Speer: Architecture, 1932-1942, (New York: Monacelli Press, 2013), vii, 219.

25 "The more fundamental form of violence [is] in language as such." Žižek, Violence, 2.

26 Tschumi, "Violence of Architecture," 128, 131.

27 Ibid, 124.

28 Ibid, 125.

29 Tschumi and Walker, Tschumi on Architecture, 16

30 Alejandro Zaera-Polo, "Well Into the $21^{\text {st }}$ Century, the Architectures of Post-Capitalism?", in El Croquis 187: Sergison-Bates Architects, 2004-2016, (Madrid: El Croquis, 2017), 252-287, 257.

31 Ibid

32 Patrik Schumacher, Facebook post, March 18, 2014, <https://www.facebook. com/patrik.schumacher.10/posts/10202631928712343>, accessed Sep 5 , 2016 . 